\title{
Serum Enzyme Tests for Megaloblastic Erythropoiesis in Anaemia in Pregnancy
}

\author{
A. F. FI.EMING,* M.B., B.CHIR.; B. A. ELLIOTT, $†$ M.D., M.C.PATH.
}

Brit. med. F., 1964, 2, 1108-1111

Megaloblastic anaemia in pregnancy has been receiving increased attention as a result of reports which give the incidence between $1.7 \%$ and $4.2 \%$ of deliveries in the British Isles (Giles and Shuttleworth, 1958 ; Hourihane et al., 1960 ; MacKenzie and Abbott, 1960 ; Ainley; 1961). In Nigeria the condition is common, and over 200 patients with severe anaemia are seen each year in University College Hospital, Ibadan (Fullerton and Watson-Williams, 1962 ; Fullerton and Turner, 1962). The incidence may be even higher, as patients with minimal anaemia and peripheral blood changes can be missed on routine antenatal investigation (Forshaw et al., 1957 ; Giles and Shuttleworth, 1958 ; MacKenzie and Abbott, 1960 ; Ainley, 1961 ; Coyle and Geoghegan, 1962 ; Hibbard, 1962). It is generally accepted now that megaloblastic erythropoiesis in pregnancy in most countries results from insufficient folic acid to meet metabolic requirements (Lowenstein et al., 1955 ; Francis and Scott, 1959 ; Chanarin et al., 1959 ; Giles and Burton, 1960), but the routine prescription of folic acid in pregnancy remains controversial.

There is no simple and efficient method for the diagnosis of folic-acid deficiency that is not open to criticism. The determination of serum folic acid presents difficulties in interpretation in pregnancy, since the level of folic acid falls progressively even during normal pregnancy (Solomons et al., 1962 ; Zachau-Christiansen et al., 1962). The value of the determination of urinary formiminoglutamic acid in the diagnosis of megaloblastic erythropoiesis in pregnancy remains doubtful, as the metabolism of histidine, the precursor of formiminoglutamic acid, is suspected to be altered in pregnancy (Chanarin et al., 1963; Berry et al., 1963). Even when a marrow biopsy is performed recognition of early megaloblastic change may be difficult.

Unless the prophylactic use of folic acid in pregnancy becomes universal, there is need for a screening test for megaloblastic change to avoid large numbers of bone-marrow biopsies. It was decided, therefore, to assess the value of serum lactate dehydrogenase (S.L.D.) and $\alpha$-hydroxybutyrate dehydrogenase (S.H.B.D.) determinations in detecting megaloblastic erythropoiesis. Extremely high S.L.D. activities were first reported in pernicious anaemia by Hess and Gehm (1955), and elevations of S.H.B.D. levels up to 50 times the normal mean value were recorded by Elliott et al. (1962). Heller et al. (1959) observed increased S.L.D. levels in megaloblastic anaemia from other causes, but Levitan et al. (1959) found no significant increase. Elliott and Wilkinson (1963) followed a progressive rise of S.H.B.D. and S.L.D. levels in a patient with pancreatic steatorrhoea treated with pancreatin, whose peripheral blood showed minimal changes only. The degree of elevation of serum enzyme activities suggested the presence of megaloblastic erythropoiesis, and this was confirmed on marrow biopsy.

This paper presents the results of a preliminary survey on S.L.D. and S.H.B.D. activities related to other parameters in 26 consecutive patients with anaemia of pregnancy admitted with packed cell volumes (P.C.V.) below $23 \%$ who had not

\footnotetext{
* Senior Registrar, Subdepartment of Haematology, University College Hospital, Ibadan, Nigeria.

t Senior Lecturer, Department of Chemical Pathology, University College Hospital, Ibadan, Nigeria.
}

received antenatal care and who showed no evidence of blood loss. Six normal pregnant women were also investigated.

\section{Materials and Methods}

Haematological Techniques.-The methods employed were those described by Dacie (1958). The reticulocytes were expressed as a percentage of red cells, but, since a high percentage in a very anaemic patient does not necessarily represent an absolute increase in reticulocytes, the count was also expressed as the reticulocyte index (R.I.). This figure relates the percentage reticulocyte count to the P.C.V., assuming a normal P.C.V. of $45 \%$. R.I. $=\frac{\text { Reticulocytes } \% \times \text { P.C.V. }}{45}$ (Giblett et al., 1956). The normal R.I. is less than 2 in healthy Nigerian blood donors. Haemoglobin genotypes were identified by paper electrophoresis in a modification of the method of Lehmann and Ager (1961), using tris-barbitone discontinuous buffer system $p \mathrm{H}$ 8.6. Marrow biopsies were obtained from the iliac crest, and the erythroid series were classified as normoblastic, early transitional megaloblastic, transitional megaloblastic, and megaloblastic.

Vitamin Assays.-Serum folic-acid activity was measured by bioassay using Lactobacillus casei as the test organism (Herbert, 1961). The total folic acid was estimated in the presence of ascorbic acid, and the free or heat-stable component in the absence of ascorbic acid (Ball and Giles, 1964). Serum vitamin $\mathrm{B}_{12}$ was measured using Lactobacillus leichmannii as the test organism in a method modified from that of Rosenthal and Sarett (1952).

Enzyme Activities.-S.L.D. activities were determined by the spectrophotometric method of Wróblewski and LaDue (1955), and the results expressed in terms of the number of $\mu$ moles of nicotinamide-adenine dinucleotide $\left(\mathrm{NABH}_{2}\right)$ oxidized per minute by 1 litre of serum. These are the international units recommended by the Joint Subcommission on Clinical Enzymes (King and Campbell, 1961); one such unit per litre is numerically equivalent to 2.08 spectrophotometric units per ml. S.H.B.D. activities were determined in the same way, except that $\alpha$-hydroxybutyrate replaced pyruvate as substrate (Rosalki and Wilkinson, 1960 ; Elliott and Wilkinson, 1961). All determinations were made at $25^{\circ} \mathrm{C}$.

\section{Results}

The clinical and haematological findings are given in the Table.

Marrow Appearances.-Biopsies were not performed on the non-anaemic pregnant women (group 1). The 26 women with anaemia were divided into four groups by their marrow appearances: two showed normoblastic erythropoiesis (group 2), three showed early transitional megaloblastic change (group 3), eight showed transitional change (group 4), and 13 were frankly megaloblastic (group 5). The marrow in all cases contained demonstrable iron. 
Clinical.-Of the 24 patients with marrow changes 17 were in the third trimester, but one patient in group 5 presented as early as the sixteenth week. Splenomegaly was present in all groups except group 2, but gross enlargement was found only in anaemic patients and was not related to other parameters of haemolytic disease. Half of the 24 patients with marrow changes had hepatomegaly, and seven of those had a raised jugular venous pressure (J.V.P.) out of a total of 12 with this finding. Two patients who showed signs of congestive cardiac failure at relatively high P.C.V. levels were thought to have concurrent endomyocardial fibrosis.

Peripheral Blood.-The lowest P.C.V. values were observed in patients with megaloblastic erythropoiesis, but others in this group had P.C.V. values up to $21 \%$. There was considerable overlapping of P.C.V. values in all the anaemic groups. The mean corpuscular haemoglobin concentration (M.C.H.C.) was either within the normal range or just below normal in all patients. Red-cell appearances were fairly constant in all the anaemic patients, showing normochromia and varing degrees of anisocytosis, macrocytosis, and polychromasia. Poikilocytosis and target cells were present in the one patient with haemoglobin SC disease. Nucleated red cells were commonly observed, particularly in the severely anaemic patients, as were immature neutrophil polymorphs, metamyelocytes, and myelocytes, and this shift to the left often masked the expected shift to the right of megaloblastic anaemia. The R.I. was raised in all patients of groups 2 and 3, 6 out of 8 in group 4, but in only 5 out of 13 in group 5.

Serum Vitamins.- In healthy Nigerians (male and female) in Ibadan the normal total serum folic acid is $4.6-22 \mathrm{~m} \mu \mathrm{g} . / \mathrm{ml}$. with a free component of less than $0.5 \mathrm{~m} \mu \mathrm{g} . / \mathrm{ml}$. Total folic-acid levels measured in three non-anaemic women were in the low normal range. In group 2 the values were normal, and marginal or low in group 3. Three patients in group 4 had normal total levels, but in one the free component was raised. In group 510 out of 13 exhibited low total values, one had a marginal level with a normal free component, and one had a normal total value, but the free folic acid was not measured. Bioassays were not performed on the serum of one patient. Serum vitamin- $B_{12}$ levels were determined and found to be normal in 14 anaemic patients.

Enzyme Activities.-The S.L.D. and S.H.B.D. values of healthy Nigerians, including pregnant women, lie below the normal upper limits of 240 and 140 international units, respectively, found in England (Elliott and Wilkinson, 1961). S.L.D. activities were normal in groups 1,2, and 3, and raised in half

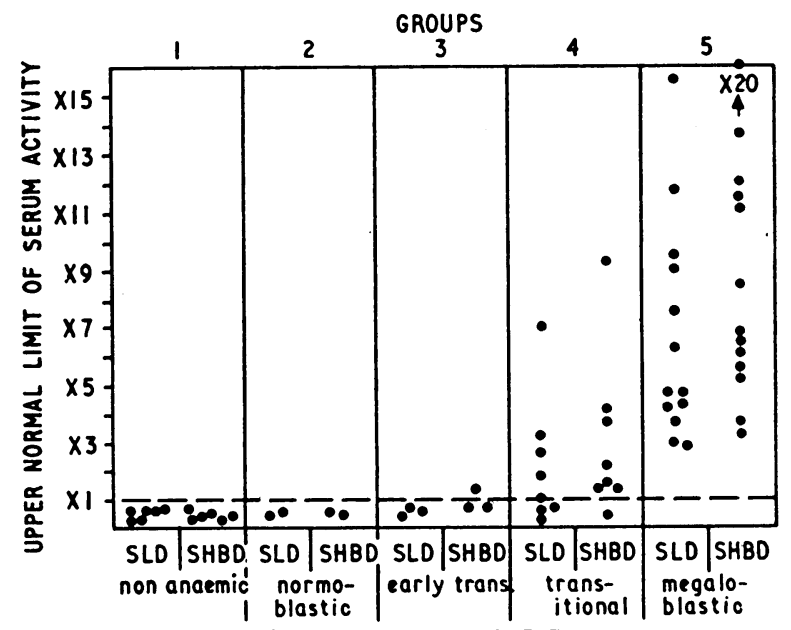

FIG. 1. - Serum lactic dehydrogenase (S.L.D.) and serum $\alpha$ hydroxybutyrate dehydrogenase (S.H.B.D.) related to bonemarrow changes.

of group 4 patients and in all 13 of group 5 patients. S.H.B.D. levels were also normal in groups 1,2 , and 3 , except for one marginally elevated value in group 3 . In group 4 one value was normal, three were marginally elevated, and four were elevated. All group 5 patients exhibited high activities (Fig. 1). For easier appreciation the serum enzyme values are expressed in terms of their upper normal limits.

Clinical and Haematological Details of Six Non-anaemic and 26 Anaemic Pregnant Women

\begin{tabular}{|c|c|c|c|c|c|c|c|c|c|c|c|c|}
\hline \multirow[t]{2}{*}{$\begin{array}{c}\text { Gestation } \\
\text { (Weeks) }\end{array}$} & \multirow{2}{*}{$\underset{(\mathrm{Cm} .)}{\text { Spleen }}+$} & \multirow{2}{*}{$\underset{(\mathrm{Cm} .)^{+}}{\text {Liver }}$} & \multirow{2}{*}{$\begin{array}{l}\text { Raised } \\
\text { J.V.P. }\end{array}$} & \multirow{2}{*}{$\stackrel{\mathrm{Hb}}{(\mathrm{g} . / 100 \mathrm{ml} .)}$} & \multirow{2}{*}{ P.C.V. } & \multirow{2}{*}{$\underset{(\%)}{\text { M.C.H.C. }}$} & \multirow{2}{*}{$\begin{array}{c}\text { Retics. } \\
(\%)\end{array}$} & \multirow{2}{*}{$\begin{array}{l}\text { Retic. } \\
\text { Index }\end{array}$} & \multirow{2}{*}{$\begin{array}{c}\text { Hb } \\
\text { Genotype }\end{array}$} & \multicolumn{2}{|c|}{$\underset{(\mathrm{m} \mu \mathrm{g} . / \mathrm{ml} .)}{\text { Serum Folic Acid }}$} & \multirow{2}{*}{$\begin{array}{c}\text { Serum } \\
\text { Vitamin } \\
\text { B } \\
\left(\mu \mu_{12}\right. \\
(\mu \mathrm{gl} / \mathrm{ml} .\end{array}$} \\
\hline & & & & & & & & & & Total & Free & \\
\hline \multicolumn{13}{|c|}{ Non-anaemic Pregnancies (Group $I$ ) } \\
\hline $\begin{array}{l}26 \\
36\end{array}$ & $\begin{array}{l}0 \\
0\end{array}$ & $\begin{array}{l}0 \\
0\end{array}$ & $\overline{-}$ & $\begin{array}{l}11 \cdot 8 \\
13.9\end{array}$ & 二 & 二 & $=$ & 二 & AA & 二 & 二 & $=$ \\
\hline 16 & 4 & 0 & $\overline{-}$ & 13.7 & 二 & 二 & 二 & 二 & AA & 二 & 二 & $=$ \\
\hline $\begin{array}{l}30 \\
26\end{array}$ & $\begin{array}{l}0 \\
0\end{array}$ & $\begin{array}{l}0 \\
0\end{array}$ & 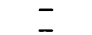 & $\begin{array}{l}13 \cdot 0 \\
12 \cdot 2\end{array}$ & $=$ & $=$ & $\bar{z}$ & $=$ & AA & $6 \cdot 2$ & $<0.5$ & 450 \\
\hline 26 & 0 & 0 & $=$ & $12 \cdot 2$ & $\overline{-}$ & 二 & 二 & $\overline{-}$ & AA & $\begin{array}{l}3.0 \\
6.2\end{array}$ & $<0.5$ & 400 \\
\hline \multicolumn{13}{|c|}{ Anaemic Pregnancies : Normoblastic (Group 2) } \\
\hline $\begin{array}{l}16 \\
20\end{array}$ & $\begin{array}{l}0 \\
0\end{array}$ & $\begin{array}{l}0 \\
0\end{array}$ & $\overline{-}$ & $\begin{array}{l}6 \cdot 8 \\
6 \cdot 1\end{array}$ & 22 & $\begin{array}{l}30 \\
29\end{array}$ & $10 \cdot 9$ & $5 \cdot 6$ & AA & $5 \cdot 0$ & - & - \\
\hline \multirow{2}{*}{\multicolumn{13}{|c|}{ Early Transitional Megaloblastic (Group 3) }} \\
\hline & & & & & & & & & & & & \\
\hline $\begin{array}{l}28 \\
36\end{array}$ & 10 & $\stackrel{8}{8}$ & \pm & $4 \cdot 6$ & $\frac{15}{20}$ & 31 & $8 \cdot 0$ & 2.7 & AA & $5 \cdot 0$ & $-\overline{0}$ & 400 \\
\hline 40 & 0 & 0 & $\overline{-}$ & 5.6 & $\begin{array}{l}20 \\
17\end{array}$ & $\begin{array}{l}36 \\
35\end{array}$ & $\begin{array}{l}4.3 \\
8 \cdot 8\end{array}$ & $\begin{array}{l}1.9 \\
3 \cdot 3\end{array}$ & AA & $\begin{array}{l}3.2 \\
2 \cdot 4\end{array}$ & $\begin{array}{l}<0.5 \\
<0.5\end{array}$ & $\bar{z}$ \\
\hline \multicolumn{13}{|c|}{ Transitional Megaloblastic (Group 4) } \\
\hline $\begin{array}{l}28 \\
28\end{array}$ & $\begin{array}{l}0 \\
0\end{array}$ & $\begin{array}{l}4 \\
8\end{array}$ & \pm & $\begin{array}{l}6.5 \\
5.9\end{array}$ & 20 & 33 & $13 \cdot 2$ & 5.9 & AA & $1 \cdot 3$ & $=$ & $\overline{625}$ \\
\hline $\begin{array}{l}28 \\
26 \\
28\end{array}$ & $\begin{array}{l}0 \\
0 \\
4\end{array}$ & $\begin{array}{l}8 \\
0 \\
4\end{array}$ & $\bar{z}$ & $\begin{array}{l}5.9 \\
5.7\end{array}$ & $\begin{array}{l}18 \\
20\end{array}$ & $\begin{array}{l}33 \\
29\end{array}$ & $\begin{array}{l}6 \cdot 6 \\
2 \cdot 8\end{array}$ & $\begin{array}{l}2 \cdot 7 \\
1 \cdot 1\end{array}$ & $\begin{array}{l}\text { AS } \\
\text { AS }\end{array}$ & $\begin{array}{l}2 \cdot 0 \\
2 \cdot 8\end{array}$ & $\overline{\overline{0}}$ & $\begin{array}{l}625 \\
950\end{array}$ \\
\hline $\begin{array}{l}28 \\
34 \\
30\end{array}$ & $\begin{array}{l}4 \\
0\end{array}$ & $\begin{array}{l}4 \\
0\end{array}$ & $\bar{z}$ & $\begin{array}{l}4 \cdot 9 \\
4 \cdot 3\end{array}$ & $\begin{array}{l}15 \\
14\end{array}$ & $\begin{array}{l}33 \\
31\end{array}$ & $\begin{array}{c}2 \cdot 0 \\
17 \cdot 3\}\end{array}$ & $\begin{array}{l}0.8 \\
5.4\end{array}$ & $\begin{array}{l}\text { AS } \\
\text { AA }\end{array}$ & $\begin{array}{l}5 \cdot 0 \\
5.9\end{array}$ & $\begin{array}{l}<0.5 \\
<0.5\end{array}$ & 575 \\
\hline $\begin{array}{l}30 \\
22\end{array}$ & $\begin{array}{r}0 \\
13\end{array}$ & $\begin{array}{r}0 \\
10\end{array}$ & $\bar{t}$ & $\begin{array}{l}8 \cdot 2 \\
6 \cdot 2\end{array}$ & $\begin{array}{l}22 \\
20\end{array}$ & $\begin{array}{l}37 \\
31\end{array}$ & $\begin{array}{r}8.0^{\circ} \\
12.0\end{array}$ & $\begin{array}{l}3.9 \\
5.3\end{array}$ & $\begin{array}{l}\text { AS } \\
\text { AA }\end{array}$ & $\begin{array}{l}7 \cdot 2 \\
1 \cdot 7\end{array}$ & $3 \cdot 4$ & $=$ \\
\hline 24 & 10 & 8 & + & $3 \cdot 6$ & 12 & 30 & 20.0 & $5 \cdot 3$ & & 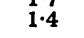 & $<\overline{0.5}$ & $\overline{475}$ \\
\hline & \multicolumn{12}{|c|}{ Megaloblastic (Group 5) } \\
\hline & & 6 & + & $2 \cdot 8$ & 8 & 35 & & & - & $1 \cdot 4$ & - & - \\
\hline $\begin{array}{l}26 \\
28 \\
16\end{array}$ & $\begin{array}{l}6 \\
6 \\
0\end{array}$ & $\begin{array}{l}6 \\
4\end{array}$ & $\stackrel{+}{-}$ & $\begin{array}{l}3.4 \\
4.7 \\
2.7\end{array}$ & $\begin{array}{l}11 \\
13\end{array}$ & $\begin{array}{l}31 \\
36\end{array}$ & $\begin{array}{l}1.0 \\
0.8\end{array}$ & $\begin{array}{l}0.2 \\
0.2\end{array}$ & $\begin{array}{l}\mathrm{AA} \\
\mathrm{AS}\end{array}$ & $\begin{array}{l}7.6 \\
1.6\end{array}$ & 二 & $\overline{600}$ \\
\hline $\begin{array}{l}16 \\
36 \\
24\end{array}$ & $\begin{array}{r}0 \\
0 \\
14\end{array}$ & $\begin{array}{l}0 \\
0 \\
0\end{array}$ & \pm & $\begin{array}{l}3.3 \\
6.1\end{array}$ & $\begin{array}{l}11 \\
18\end{array}$ & $\begin{array}{l}30 \\
34\end{array}$ & $\begin{array}{r}20.0 \\
1.3\end{array}$ & $\begin{array}{l}4.9 \\
0.5\end{array}$ & $\begin{array}{l}\mathrm{AC} \\
\mathrm{AA}\end{array}$ & $\begin{array}{l}1 \cdot 6 \\
2 \cdot 4\end{array}$ & $=$ & $\begin{array}{l}600 \\
625\end{array}$ \\
\hline $\begin{array}{l}24 \\
34\end{array}$ & $\begin{array}{l}48 \\
6 \\
0\end{array}$ & $\begin{array}{l}0 \\
0 \\
0\end{array}$ & + & $\begin{array}{l}4.1 \\
4.0\end{array}$ & 11 & 37 & $\begin{array}{l}5.0 \\
4.5\end{array}$ & $\begin{array}{l}1.4 \\
1.1\end{array}$ & $\begin{array}{l}\text { AA } \\
\text { AA }\end{array}$ & $\overline{2 \cdot 2}$ & $<0.5$ & $\overline{450}$ \\
\hline $\begin{array}{l}34 \\
30\end{array}$ & $\begin{array}{r}10 \\
4\end{array}$ & $\begin{array}{l}6 \\
4\end{array}$ & $\bar{z}$ & $\begin{array}{l}4.0 \\
4.0 \\
7.7\end{array}$ & $\begin{array}{l}13 \\
12\end{array}$ & $\begin{array}{l}31 \\
33\end{array}$ & $\begin{array}{l}0.8 \\
1.6\end{array}$ & $\begin{array}{l}0.2 \\
0.4\end{array}$ & $\begin{array}{l}\text { AA } \\
\text { SC }\end{array}$ & $\begin{array}{l}1.8 \\
4.6\end{array}$ & $\begin{array}{l}<0.5 \\
<0.5\end{array}$ & $\begin{array}{l}800 \\
375\end{array}$ \\
\hline $\begin{array}{l}28 \\
36\end{array}$ & $\begin{array}{c}12 \\
0\end{array}$ & $\begin{array}{l}4 \\
0 \\
5\end{array}$ & $\mp$ & $\begin{array}{l}7.7 \\
4 \cdot 0 \\
3.3\end{array}$ & $\begin{array}{l}21 \\
14\end{array}$ & $\begin{array}{l}36 \\
29\end{array}$ & $\begin{array}{r}5.5 \\
19.0\end{array}$ & $\begin{array}{l}2.6 \\
5.9\end{array}$ & $\begin{array}{l}\mathrm{AA} \\
\mathrm{AA}\end{array}$ & $\begin{array}{l}1.4 \\
0.8\end{array}$ & $\begin{array}{l}<0.5 \\
<0.5\end{array}$ & 400 \\
\hline 28 & 0 & 0 & + & 2.7 & 11 & $\begin{array}{l}50 \\
30\end{array}$ & $\begin{array}{r}11.0 \\
4.0\end{array}$ & $\begin{array}{l}2.7 \\
0.8\end{array}$ & $\mathrm{AA}$ & $\begin{array}{l}1.7 \\
1.0\end{array}$ & $<\overline{0.5}$ & 450 \\
\hline
\end{tabular}




\section{Discussion}

The high incidence of megaloblastic erythropoiesis in anaemia of pregnancy in the Ibadan area is confirmed by the fact that 24 out of 26 consecutive patients with severe anaemia gave some evidence of marrow changes. These changes were associated with normal serum vitamin- $B_{12}$ levels in all 14 patients where it was measured, and with low total serumfolic-acid activity in groups 4 and 5 . There were two exceptions with normal values, and these might have resulted from contamination or from an increased concentration of free folic acid with a lowered heat-labile active fraction (Ball and Giles, 1964). High free folic acid was present in one group 4 patient, but the importance of measuring this fraction was not appreciated when the other two patients presented.

In Nigeria many patients with anaemia in pregnancy show evidence of a haemolytic process which appears to be related in some way to chronic Plasmodium falciparum infection (Fullerton and Watson-Williams, 1962). Nine out of 12 patients in groups 2,3 , and 4 , and 5 out of 13 in group 5 had on admission high R.I., hyperplastic marrows, but no evidence of blood loss. The P.C.V. values were slow to rise and the R.I. remained elevated after treatment with folic acid, and it was considered that haemolysis was continuing. Only a small proportion of anaemias in pregnancy are due to haemoglobinopathies, and in the present series there was one patient with haemoglobin SC disease. She had a normal R.I. and a hypoplastic megaloblastic marrow. The 10 other patients with a normal R.I. had active transitional or megaloblastic marrows, responded completely to folic acid, and were thought to be patients with uncomplicated folic-acid deficiency.

Since L.D. and H.B.D. are present in all tissues, there were several possible sources of increased serum activities in these patients. Acute intravascular haemolysis may give rise to elevated S.L.D. and S.H.B.D. levels, but a chronic process has

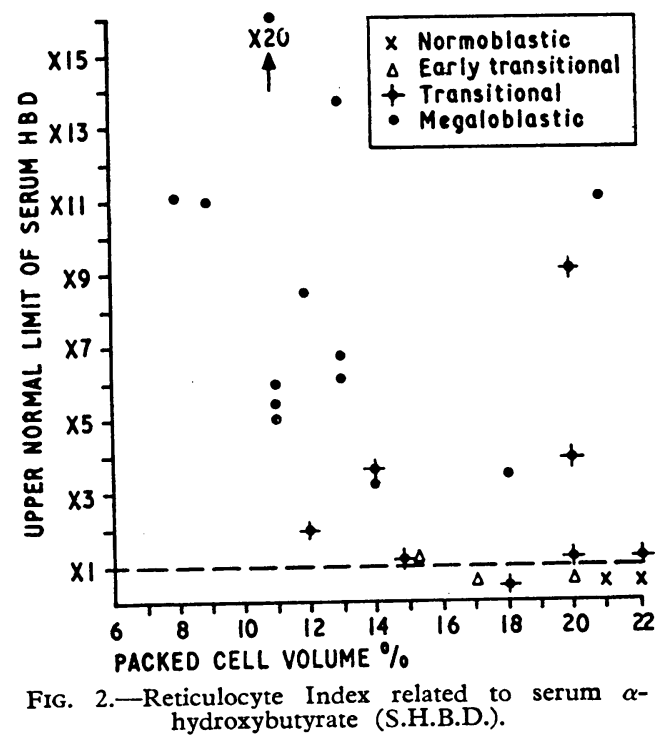

little effect, probably as a result of the efficient clearance mechanisms for these enzymes (Elliott and Wilkinson, 1963). In the present series there was no correlation between elevated serum enzyme levels and haemolysis; on the contrary, most patients with very high S.L.D. and S.H.B.D. activities had a normal R.I. (Fig. 2). It is unlikely that abnormal enzyme findings resulted from generalized hypoxic damage secondary to anaemia itself, as there was no clear correlation between the degree of anaemia and the elevation of enzyme activities (Fig. 3). Eight patients in the present series were in incipient congestive cardiac failure. This condition may cause liver damage and be associated with a rise in serum transaminase levels, but has no marked effect on S.L.D. activities, and usually none on S.H.B.D. (Elliott et al., 1962). Conditions which give rise to marked S.L.D. and S.H.B.D. elevationsacute myocardial damage, carcinomatosis, and acute leukaemia -may occur in pregnancy. The first two of these should be diagnosed on clinical and other grounds, and the marrow biopsy should demonstrate leukaemia. Endomyocardial fibrosis, present in two patients under study, is not associated with significant elevations in enzyme activities (Elliott, umpublished observations).

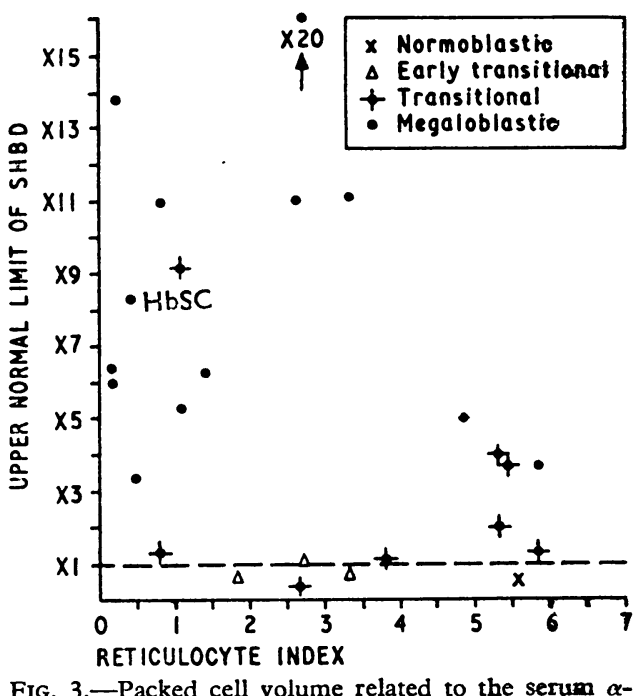

FIG. 3.-Packed cell volume related to the serum $\alpha$ hydroxybutyrate (S.H.B.D.).

The finding of a definite correlation between elevated S.L.D. and S.H.B.D. levels and megaloblastic erythropoiesis suggests the determination of their activities as a relatively simple method, applicable on a large scale, of detecting these marrow changes. Colorimetric procedures are available for centres with no spectrophotometer (King, 1959 ; Rosalki, 1962). The fact that serum enzyme elevations are related to marrow changes rather than to the degree of anaemia may have particular relevance to patients with marrow changes but minimal anaemia. S.H.B.D. activities reacted more than those of S.L.D. and detected most cases in the transitional stage. This higher sensitivity and the reduced risk of abnormal resuits from other causes favour the use of S.H.B.D. It is concluded that the determination of S.L.D. and S.H.B.D. activities merits further investigation as a potential screening test for megaloblastic erythropoiesis in patients attending antenatal clinics where folic acid is not routinely prescribed.

\section{Summary}

Serum lactate dehydrogenase (S.L.D.) and $\boldsymbol{\alpha}$-hydroxybutyrate dehydrogenase (S.H.B.D.) activities were determined in 26 patients with severe anaemia of pregnancy. Thirteen patients with megaloblastic erythropoiesis had elevated activities of both serum enzymes; and of eight patients with transitional marrow changes the S.L.D. was abnormal in four and the S.H.B.D. in seven. Early transitional megaloblastic erythropoiesis present in three patients was not associated with abnormal enzyme levels. S.H.B.D. activities were more sensitive to marrow changes than those of S.L.D., and are less likely to be elevated from other causes. The determination of S.L.D. or S.H.B.D. activities has potentialities as a simple screening test for megaloblastic erythropoiesis in pregnancy.

We are grateful to Professor J. B. Lawson, Professor J. C. Edozien, and Dr. N. C. Allan for helpful advice and criticism. We also thank our colleagues of the Department of Obstetrics and Gynaecology for permission to study patients under their care, and Mr. A. K. Afolabi, a medical student, for technical assistance. 


\section{REFERENCES}

Ainley, N. J. (1961). f. Obstet. Gynaec. Brit. Cwlth, 68, 254

Ball, E. W., and Giles, C. (1964). ₹. clin. Path., 17, 165.

Berry, V., Booth, M. A., Chanarin, I., and Rothman, D. (1963). Brit. med. F., 2, 1103 .

Chanarin, I., MacGibbon, B. M., O'Sullivan, W. J., and Mollin, D. L. (1959). Lancet, 2, 634 .

Rothman, D., and Watson-Williams, E. J. (1963). Ibid., 1, 1068.

Coyle, C., and Geoghegan, F. (1962). Proc. roy. Soc. Med., 55, 764.

Dacie, J. V. (1958). Practical Haematology. Churchill, London.

Elliott, B. A., Jepson, E. M., and Wilkinson, J. H. (1962). Clin. Sci., 23, 305 .

and Wilkinson, J. H. (1961). Lancet, 1, 698.

- (1963). Clin. Sci., 24, 343.

Forshaw, J. W. B., Jones, A. T., Chisholm, W. N., and McGinley, W. K. (1957). F. Obstet. Gynaec. Brit. Emp., 64, 255.

Francis, H. H., and Scott, J. S. (1959). Lancet, 2, 1033.

Fullerton, W. T., and Turner, A. G. (1962). Ibid., 1, 75.

and Watson-Williams, E. J. (1962). f. Obstet. Gynaec. Brit. Cwlth, 69, 729.

Giblett, E. R., Coleman, D. H., Pirzio-Biroli, G., Donohue, D. M., Motulski, A. G., and Finch, C. A. (1956). Blood, 11, 291.

Giles, C., and Burton, H. (1960). Brit. med. F., 2, 636.

Giles, C., and Shuttleworth, E. M. (1958). Lancet, 2, 1341.
Heller, P., West, M., and Zimmerman, H. J. (1959). Clin. Res., 7, 207.

Herbert, V. (1961). F. clin. Invest., 40, 81

Hess, B., and Gehm, E. (1955). Klin.'Wschr., 33, 91.

Hibbard, E. D. (1962). F. Obstet. Gynaec. Brit. Cwlth, 69, 739.

Hourihane, B., Coyle, C. V., and Drury, M. I. (1960). F. Irish med. Ass., 47, 1 .

King, E. I., and Campbell, D. M. (1961). Clin. chim. Acta, 6, 301.

King, E. J., and Campbell, D. M. (1961). Clin. ch
King, J. (1959). 7. med. Lab. Technol., 16, 265.

Lehmann, H., and Ager, J. A. M. (1961). Association of Clinical Pathologists, Broadsheet No. 33.

Levitan, R., Wasserman, L. R., and Wróblewski, F. (1959). Clin. Res. 7, 217 .

Lowenstein, L., Pick, C., and Philpott, N. (1955). Amer. F. Obstet. Gynec., 70, 1309 .

MacKenzie, A., and Abbott, J. (1960). Brit. med. f., 2, 1114.

Rosalki, S. B.'(1962). F. clin. Path., 15, 566.

Rosalki, S. B. (1962). F. Clin. Path., 15, 566.

Rosenthal, H.' L., and Sarett, H. P. (1952). F. biol. Chem., 199, 433.

Solomons, E., Lee, S. L., Wasserman, M., and Malkin, J. (1962). F. Obstet. Gynaec. Brit. Cwlth, 69, 724.

Wróblewski, F., and LaDue, J. S. (1955). Proc. Soc. exp. Biol. (N.Y.) 90, 210 .

Zachau-Christiansen, B., Hoff-Jørgensen, E., and Østergård Kristensen, H. P. (1962). Dan. med. Bull., 9, 157.

\title{
Influence of Sex and ABO Blood Group on the Normal Lymphocyte Transfer Test
}

\author{
J. F. MOORHEAD, $* \dagger$ M.B., M.R.C.P. ; A. R. PATEL,* M.B., CH.M., F.R.C.S.
}

Brit. med. F., 1964, 2, 1111-1113

Considerable interest has recently been shown in the normal lymphocyte-transfer test, first described by Brent and Medawar (1963). They showed that in guinea-pigs a local reaction of varying intensity was produced by the intradermal injection of homologous lymphocytes. This reaction was correlated with the order of rejection of skin grafts when these were made from the lymphocyte recipients to the lymphocyte donor. A similar test was carried out in human beings by Gray and Russell (1963), Bridges et al. (1964), and Goldsmith (1964).

Since the influence of $A B O$ blood group and sex on the reaction has not been previously reported in humans, an experiment was designed to evaluate these factors. At the same time an opportunity was taken to obtain detailed information about the reaction.

\section{Preparation of Lymphocytes}

Aseptic precautions were observed throughout the procedure. Thirty millilitres of blood was defibrinated at room temperature by gentle shaking in a conical flask containing 12 glass beads. Then $25 \mathrm{ml}$. of $3 \%$ Dextraven in normal saline was added and the suspension allowed to sediment for 30 minutes at $37^{\circ} \mathrm{C}$., so that most of the red cells, neutrophils, and platelets separated out, leaving a high concentration of lymphocytes in the supernatant. The latter was then aspirated into a glass tube and centrifuged for 10 minutes at 1,500 r.p.m. The top layer was discarded from the tube except for approximately $1.5 \mathrm{ml}$., which was used to re-suspend the deposited cells. These were allowed to sediment at $37^{\circ} \mathrm{C}$. for 45 minutes in order to remove more of the contaminating red cells, and the final supernatant containing a high concentration of lymphocytes was placed in a glass container. The number of lymphocytes

* From the Nuffield Unit of Medical Genetics in the Department of Medicine, University of Liverpool, and the Artificial Kidney Unit, Sefton General Hospital, Liverpool.

+ Now at Renal and Electrolyte Division, Georgetown University Hospital, Washington, D.C. obtained in this way varied from $10 \times 10^{6}$ to $50 \times 10^{6}$ per ml. in a total volume of approximately $1-1.5 \mathrm{ml}$. The final preparation was contaminated with red cells to the extent of 50 to $75 \%$ of the number of lymphocytes. Few neutrophils and platelets remained. This preparation was tested each time for bacteriological sterility, and no organisms were cultured from any preparation. The lymphocyte viability was tested with trypan blue ; the number of dead cells was never more than $1 \%$.

Tests done at the National Institute for Medical Research demonstrated that $3 \%$ dextran in normal saline was completely non-toxic to lymphocytes.

\section{Experiment}

Twenty-four accredited blood donors (volunteers) were used, 12 of each sex. In order to avoid the possible dangers of $\mathrm{Rh}$ sensitization (because a few red cells are inevitably injected), all the women volunteers were post-menopausal. The men were in the age-group 45-55 years.

The design, purpose, and possible dangers of the experiment were fully explained to every volunteer on at least two occasions. Four of the 24 volunteers (two men and two women) donated lymphocytes; the remaining 20 each received one lymphocyte dose from all four donors. The recipients were all group A, $\mathrm{Rh}$-positive, while the donors consisted of two males-one $\mathrm{A}$, $\mathrm{Rh}$-positive, and the other B, Rh-positive-and two femalesone A, Rh-positive, and the other B, Rh-positive. Some of the other minor blood groups were also determined, and these are recorded in Table $\mathrm{I}$.

It had been found in the pilot experiments (see below), using different body sites, that the upper part of the flexor aspect of the forearm was the most suitable for reading results, and this area was therefore chosen for subsequent tests. The sites were numbered 1 to 4 from right to left, there being two sites on each arm. In order to eliminate as far as possible the 